\title{
ENTREVISTA COM O PROFESSOR ALFREDO PEREIRA JUNIOR
}

\section{Alfredo Pereira Junior}

Professor Doutor do Departamento de Educação do Instituto de Biociências da UNESP - Campus de Botucatu, e docente no Programa de Pós Graduação em Filosofia da Faculdade de Filosofia e Ciências - UNESP - Campus de Marília. E-mail: alfredo.pereira@unesp.br

\section{Antônio Sergio da Costa Nunes}

Professor de Filosofia na Universidade Federal do Pará. Pósdoutor em Filosofia Ecológica pela UNESP de Marília-SP. Email: ascn@ufpa.br

Alfredo Pereira Jr. possui graduação em Filosofia pela Universidade Federal de Juiz de Fora (1984), graduação em Administração de Empresas pela Fundação de Ciências Contábeis e Administrativas Machado Sobrinho (1983), mestrado em Filosofia pela Universidade Federal de Minas Gerais (1986) e doutorado em Lógica e Filosofia da Ciência pela Universidade Estadual de Campinas (1994). Realizou Pós-Doutorado em Ciências do Cérebro e da Cognição no Massachusetts Institute of Technology (1996-98). Livre-Docente, Professor Adjunto II da Universidade Estadual Paulista Júlio de Mesquita Filho.

\section{A.S.C. Nunes - Qual é a conexão que te permite fazer uma leitura das questões referentes à ecologia e ao pensamento de Heidegger?}

A.P. Júnior - Heidegger possui referências à floresta, e também tem a famosa tese filosófica dele de que a técnica propiciaria o Esquecimento do Ser. O Desvelamento do Ser seria ligado a um processo espontâneo, no qual se tem uma experiência direta, uma presença junto às plantas, às florestas, etc, que seriam o ambiente onde o Ser se manifesta. Também haveria uma espécie de uma separação, de uma dicotomia, uma falta de continuidade entre a história do Ser e a cultura técnica, que provocaria certa ruptura nesse processo espontâneo e, consequentemente, o Esquecimento do Ser. Na nossa visão (ecológica), diferentemente de 
Heidegger, a técnica poderia estar em continuidade com a natureza; nos animais, por exemplo, o pássaro faz o ninho, o castor faz uma barreira e já nos povos nativos, se observa elaborações técnicas em perfeita comunhão com a natureza.

\section{A.S.C. Nunes - Eu tenho uma questão epistemológica muito importante para tratar, a compreensão do pensamento do Heidegger. Ele foi discípulo de Edmund Husserl, o mais radical dos cartesianos. Nesse sentido, o Sr. não acha que o Heidegger dicotomiza essa categoria entre o Ser e o Esquecimento ou se há um lastro de cartesianismo?}

A.P. Júnior - Com base no que eu conheço de Heidegger, ele coloca o início do esquecimento do Ser em Aristóteles, e não em Platão. Descartes está mais ligado ao lado platônico, e disso vem o seguinte questionamento: por que o esquecimento do Ser em Aristóteles? Porque em Aristóteles se começa a tratar da realidade na linguagem e na lógica, ao invés do pensamento platônico, que postula a presença das ideias. Na visão de Heidegger, acredito que pelo desenvolvimento da lógica, e da abordagem da ontologia a partir da linguagem, ocorreria o Esquecimento do Ser. É possível que Heidegger tenha se inspirado em filosofias orientais, como as da Não-Dualidade. A diferença de Platão e Heidegger não estaria no modo de se relacionar com o real, que seria pela presença: o que muda seria que Platão considera como primeira realidade o Mundo das Ideias, porque o mundo da natureza é o mundo das aparências. Porém, para Heidegger, ao entrar pela floresta, nos encontramos na presença do Ser; se o mundo das aparências é o mundo real, isso simboliza uma ruptura com o platonismo.

\section{A.S.C. Nunes - Mudando de assunto, agora lhe pergunto sobre o Monismo de Triplo Aspecto, onde se sustentam três aspectos primordiais: o físico-químico-biológico, o informacional e o mental consciente (subjetividade). Por que cada um desses aspectos é fundamental?}

A.P. Júnior - O Monismo de Triplo Aspecto é uma abordagem que eu chamo de "ontologia interdisciplinar baseada na experiência”, mas incluindo também a experiência científica e tecnológica. A questão, na verdade, seria sobre quais aspectos ou características da realidade seriam fundamentais para que a nossa experiência no mundo científico-tecnológico seja do modo como ela é. Ou seja, quais categorias ontológicas seriam essenciais? Porque, hoje em 
dia, há o debate acadêmico: tudo se reduziria à matéria, à mente, ou, como na opinião de alguns físicos, tudo seria informação, ou seja, "It from Bit”? Então, o raciocínio que eu faço é que se você levar em conta as variadas conquistas científicas, tecnológicas, a experiência cotidiana e também o conhecimento filosófico, você chega a essas três categorias citadas. Há argumentos específicos para cada uma dessas vertentes, por exemplo, por que a matéria é fundamental? Porque você precisa comer para viver; caso você não se alimente, você morre. A partir disso, vemos a matéria como algo fundamental para as nossas vidas, já a informação é concebida como uma forma que se transmite. Exemplificando, você possui certa quantidade de bits de informação no disco rígido do seu computador e passou para o seu pen drive, você não passou matéria, passou-se um padrão, isto é, a informação, uma forma que está num substrato material que passa para outro. As interações humanas na atualidade ocorrem desta maneira. E sobre a questão da consciência, a base da cognição é o processamento de informação, como no Deep Blue (computador que joga xadrez). Essa máquina processa a informação, mas não é consciente. Se reproduz na inteligência artificial o processamento de informação em máquinas, mas comparando-as conosco, sabemos que falta a consciência, e há a hipótese de que a consciência esteja ligada aos sentimentos. Podemos constatar na nossa experiência que enquanto estamos conscientes sempre experimentamos sentimentos.

\section{A.S.C. Nunes - O Sr. falou em relação ao que torna a mente consciente: são os sentimentos. Poderia nos falar sobre uma evidência?}

A.P. Júnior - Citando um caso, seria quando os médicos consideram que uma pessoa não está mais consciente, no caso da anestesia. Isso ocorre quando ela não sente mais dor durante uma cirurgia. $\mathrm{O}$ ato de sentir dor é um critério usado na prática, para demonstrar consciência. Até as operações matemáticas podem ser feitas de modo inconsciente. A inteligência e o pensamento não são critérios para a consciência, pois há máquinas que são muito inteligentes, mas não possuem consciência.

\section{A.S.C. Nunes - Já foi mencionado anteriormente, sobre o processamento da matéria, da informação com os humanos. Porém, os sentimentos possuem relação com os outros seres vivos? Se sim, qual seria sua justificativa?}


A.P. Júnior - Esse sentir não é exclusivo da nossa espécie, se faz presente em todos os animais e plantas, em princípio. Agora, o critério que eu uso, é a presença de um certo tipo de onda iônica. Este critério foi elaborado quando eu iniciei minha pesquisa com os astrócitos, que são células presentes no sistema nervoso, que possuem uma fisiologia diferente dos neurônios. Basicamente, a atividade fisiológica relevante destas células é a onda de cálcio, que se propaga no tecido, se diferindo da atividade dos neurônios, o potencial de ação, que se propaga de célula para célula. As ondas de cálcio acontecem em todos os seres multicelulares, como as plantas, que também têm potenciais elétricos semelhantes aos dos animais. Em resumo, todos os seres vivos multicelulares apresentam as ondas de cálcio, que formam o correlato biológico dos sentimentos, já a atividade dos neurônios, que está ligada com a racionalidade, apenas animais apresentam. As plantas possuem Sentiência, a capacidade de sentir, a sensibilidade que os organismos vivos possuem, onde elas sentem a terra, a chuva, o toque de um inseto, etc, mas, obviamente, não sentem emoções humanas nem pensam como a gente.

\section{A.S.C. Nunes - Para encerrar, gostaria de fazer mais um questionamento. Sendo mais específico, digamos que se eu tiver uma bactéria e jogar um veneno para eliminá-la, ela como ser unicelular e por ter componentes bioquímicos, não deveria sentir alguma coisa?}

A.P. Júnior - Precisa-se de um coletivo de células para que a Sentiência aconteça. No caso, de uma população de bactérias ou de fungos, eu acredito que a bactéria individual não teria o mecanismo necessário para gerar o sentimento, mas um coletivo delas sim. A ideia seria de que o sentir é um processo temporal, como a música, porque não existe música instantânea; para a música ser gerada na fisiologia do ser vivo, seria preciso uma estrutura multicelular. É uma hipótese, mas não tenho como garantir se uma bactéria isolada sente ou não sente o mundo ao seu redor.

JÚNIOR, Alfredo. P. Entrevista com Alfredo Pereira Júnior. Complexitas - Rev. Fil. Tem. Belém, v. 2, n. 2, p. 2-5, jul./dez. 2017. Entrevista concedida a Antonio Sergio da Costa Nunes. Disponível em: $<$ http://www.periodicos.ufpa.br/index.php/complexitas/article/view/6594>. Acesso em: $07 \mathrm{de}$ janeiro de 2019. 